\title{
Paramecium jenningsi Species Complex (Ciliophora, Protista) in India: the First Description of New Stands of $P$. bijenningsi and $P$. trijenningsi
}

\author{
Ewa PRZYBoŚ, Chaganti KAlAVATI, Sergei I. FOKIN, and Sebastian TARCZ
}

Przyboś E., Kalavati C., FoKin S.I., TARCZ sincerely. 2017. Paramecium jenningsi species complex (Ciliophora, Protista) in India: the first description of new stands of $P$. bijenningsi and P. trijenningsi. Folia Biologica (Kraków) 65: 55-61.

Paramecium jennngsi (Ciliophora, Protista) is a complex of three cryptic species known from 13 sampling points situated around the world, mainly in the tropics. Two strains recently collected in India were identified as $P$. bijenningsi and $P$. trijenningsi from the $P$. jenningsi complex, based on an analysis of 16 (both nuclear and mitochondrial) loci, strain crosses, and cytological analyses. Current results increase the knowledge about the species range of particular members of the $P$. jenningsi complex.

Key words: Ciliates, Paramecium jenningsi species complex, multi-loci analysis, strain crosses, cytological analysis

Ewa PRZYBOŚ, Sebastian TARCZ, Institute of Systematics and Evolution of Animals, Polish Academy of Sciences, Kraków 31-016, Stawkowska 17, Poland.

E-mail:przybos@isez.pan.krakow.pl

Chaganti KALAVATI, Department of Zoology, Andhra University, Visakhapatnam, India.

Sergei I. FOKIN, Department of Biology, University of Pisa, Pisa, Italy

Microbial eukaryotes are one the of the main components of tropical food webs in different ecosystems. However, our knowledge of their biodiversity is still significantly underestimated (MEDINGER et al. 2010). Even in Paramecium (one of the best studied genera of microbial eukaryotes), the problem of under-sampling is still a concern in less frequently studied parts of the world, particularly the southern hemisphere (FOKIN 2010/2011). Similarly, data concerning the occurrence of particular species from the tropics are rare. One of the Paramecium morphospecies with preference for a warm climate and therefore poorly studied as concerns its range and biodiversity is $P$. jenningsi (DILLER \& EARL 1958). Although up to now it was collected in only 13 sampling sites distributed worldwide but situated mainly in the tropics (PRZYBOŚ et al. 1999), it was suggested (PRZYBOŚ et al. 1999, 2003; MACIEJEWSKA 2007) and then confirmed by strain crosses, morphological and molecular analyses (PRZYBOŚ \& TARCZ 2013) to be a complex of three cryptic species (PRZYBOŚ \& TARCZ 2016). Moreover, two of them are known from one ( $P$. primjenningsi) or two (P. bijenningsi) southern Asian locations in contrast to $P$. trijenningsi collected from the Japanese islands (6 sampling points), Africa (2 sampling points) and Americas (2 sampling points). With reference to the above, every new sampling point of $P$. jenningsi complex should bring key information about its biogeography and cryptic diversity. In the present study, based on strain crosses, cytological analyses as well as a comparison of 11 nuclear and 5 mitochondrial loci, we showed the Paramecium species affiliation of two strains collected in India in 2014.

\section{Material and Methods}

\section{Material}

The two investigated strains (designated KT1 and MVP1) of the $P$. jenningsi complex (Table 1) originated from India, Andhra Pradesh, Visakhapatnam. More precisely, the KT1 strain was collected in the Kottura, a freshwater pond $\left(18^{\circ} 5^{\prime} 34.76 " \mathrm{~N}\right.$, 
Table 1

Strains of the Paramecium jenningsi complex used in present studies

\begin{tabular}{|c|c|c|c|c|c||}
\hline No & Species & $\begin{array}{c}\text { Strain } \\
\text { index }\end{array}$ & $\begin{array}{c}\text { Strain geographical } \\
\text { origin }\end{array}$ & Collector's name & Reference \\
\hline \hline 1. & Paramecium bijenningsi & MVPI & India, Andra Pradesh & $\begin{array}{l}\text { Valentina SERRA } \\
\text { and Charan Kumar BASURI }\end{array}$ & unpublished \\
\hline 2. & Paramecium trijenningsi & KTI & India, Andra Pradesh & $\begin{array}{l}\text { Sergei I. FOKIN, Valentina SERRA } \\
\text { and Charan Kumar BASURI }\end{array}$ & SERRA et al. 2014 \\
\hline
\end{tabular}

$83^{\circ} 8^{\prime} 10.56 " \mathrm{E}$ ) on $27 / 01 / 2014$. The MVP1 strain was sampled in a wastewater stream in MVP Colony, which is an urban neighbourhood of the city of Visakhapatnam $\left(17^{\circ} 44^{\prime} 14.63^{\prime \prime N}, 83^{\circ} 20^{\prime} 16.79^{\prime \prime} \mathrm{E}\right)$ on $24 / 03 / 2014$. The general morphology and nuclear apparatuses in vegetative and autogamous individuals are characterized by cytological preparations (presented in Fig. 1), and the dimensions of particular strains are given in Table 3.

\section{Strain cultivation}

Paramecia were cultured in a medium made of dried lettuce and distilled water inoculated with Enterobacter aerogenes according to the methods of SONNEBORN $(1950,1970)$ and supplemented with $0.8 \mu \mathrm{g} / \mathrm{ml} \mathrm{B}$ sitosterol (Merck, Darmstadt, Germany). Methods used in cytological studies, strain measurements, and crosses, as well as molecular analyses were as in PRZYBOŚ and TARCZ (2016).
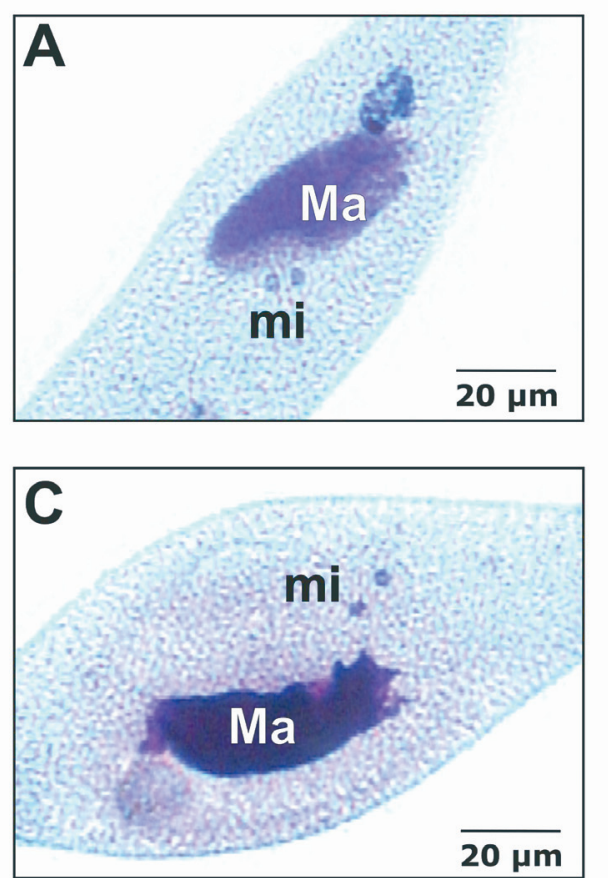

Molecular methods and data analysis

Paramecium genomic DNA was isolated from vegetative cells at the end of the exponential phase (approx. 1000 cells were used for DNA extraction). Eleven nuclear and five mitochondrial DNA fragments were amplified, sequenced and analyzed. The above techniques as well as the nucleotide sequences of the primers used for amplification and sequencing were described in detail in PRZYBOŚ and TARCZ (2016). The DNA sequences of both newly identified strains from India are available from the NCBI GenBank database (see Table 2). The studied sequences were aligned using ClustalW (THOMPSON et al. 1994) as part of BioEdit software (HALL 1999) and checked manually. All of the obtained sequences were unambiguous and incorporated in analysis. Phylograms were constructed for the studied fragments as in PRZYBOŚ and TARCZ (2016).
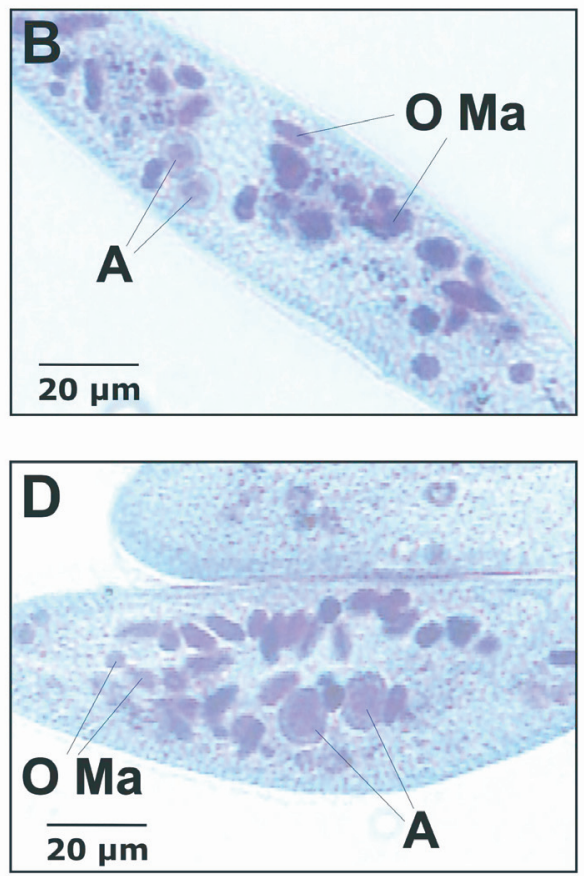

Fig. 1. A - strain MVPI of P. bijenningsi. Vegetative individual, macronucleus (Ma), two micronuclei (mi). B - strain MVPI of P. bijenningsi. Autogamous individual, fragmented old macronucleus (OMa), two macronuclear anlagen (A) with chromatin centre $\mathrm{C}$-strain RTI of $P$. trijenningsi. Vegetative individual, macronucleus (Ma), two micronuclei (mi). D - strain KTI of $P$. trijenningsi Autogamous individual, fragmented old macronucleus (OMa), two macronuclear anlagen (A) with chromatin centre. 


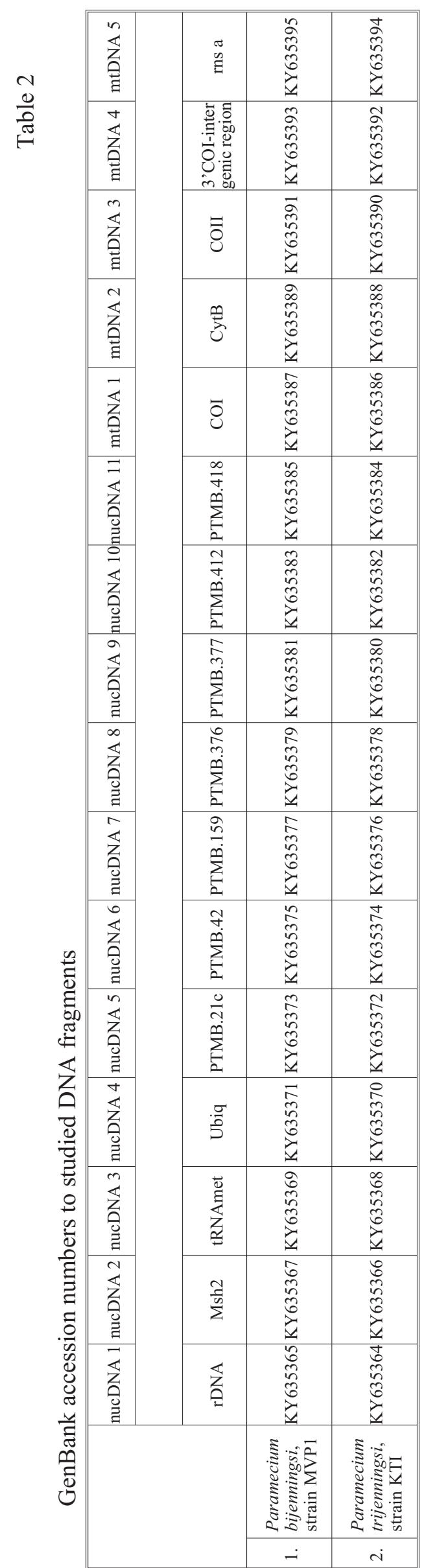

\section{Results and Discussion}

Cytological characteristics of strains from the $P$. jenningsi complex

The strains are characterized by two micronuclei (Figs 1A,C) of chromosomal type with a reticular structure (FOKIN 1997; PRZYBOŚ et al. 2015) and two macronuclear anlagen with chromatin centres (DILlER \& EARL 1958; MITCHELl 1963; PRZYBOŚ 1975, 1986; PRZYBOŚ et al. 2003; PRZYBOŚ \& TARCZ 2013) seen at a later stage of nuclear reorganization in sexual processes (autogamy, conjugation) (Figs 1B,D). Paramecia have the shape of a cigar, with two contractive vacuoles on the dorsal side, usually with 8 long radial canals.

\section{Dimensions of strains}

The dimensions (length and width of cells and macronuclei) of the strains (fixed, Giemsa-stained) and diameter of micronuclei are given in Table 3. The average length of the cells in the strain MVPI equals $248.03 \mu \mathrm{m}$, and $228.15 \mu \mathrm{m}$ in the strain KTI. The diameter of micronuclei did not show much variation between the strains $(3.12-3.85 \mu \mathrm{m}$ in both strains).

Biology - the appearance of sexual processes

Autogamy (leading to homozygosity of all genes) was observed in strains that were starved for 16-20 fissions (as an inter-autogamous period between successive autogamies) in daily isolated lines (d.i.l.) cultivated at $27^{\circ} \mathrm{C}$ in a medium enabling three fissions daily. In turn, conjugation was obtained on the sixth or seventh day of clone culture at $27^{\circ} \mathrm{C}$ at a rate of three fissions daily. The cytoplasmic type of mating type inheritance is characteristic for the species.

Identification of species and results of strain crosses

Strain MVPI was identified as $P$. bijenningsi and strain KTI as $P$. trijenningsi, based on conjugation between the studied strains and the reference strains of the particular species, i.e. the strain CS from China, Shanghai, reference for P. bijenningsi, and the strain JH from Japan, Honshu Island, Hagi, reference for $P$. trijenningsi. The percentage of surviving hybrid clones in F1 and F2 was high (Table 4). The results of the strain crosses are in concordance with the results of multi-locus analyses of the studied strains of the $P$. jenningsi complex (Figs 2,3). 
Table 3

Dimensions of studied strains of the $P$. jenningsi complex

\begin{tabular}{|l|l|c|c|c|c|c|c|c|c|c|c|}
\hline No & $\begin{array}{l}\text { Strain, } \\
\text { species }\end{array}$ & $\begin{array}{c}\text { Average } \\
\text { length } \\
\text { of cells } \\
(\mu \mathrm{m})\end{array}$ & $\mathrm{SD}$ & $\begin{array}{c}\text { Average } \\
\text { cell } \\
\text { width } \\
(\mu \mathrm{m})\end{array}$ & $\mathrm{SD}$ & $\begin{array}{c}\text { Average } \\
\text { length } \\
\text { of MAC } \\
(\mu \mathrm{m})\end{array}$ & $\mathrm{SD}$ & $\begin{array}{c}\text { Average } \\
\text { width } \\
\text { of MAC } \\
(\mu \mathrm{m})\end{array}$ & $\mathrm{SD}$ & $\begin{array}{c}\text { Average } \\
\text { diameter } \\
\text { of MIC } \\
(\mu \mathrm{m})\end{array}$ & $\mathrm{SD}$ \\
\hline 1. & $\begin{array}{l}\text { P. bijenningsi, } \\
\text { MVPI }\end{array}$ & 248.03 & 26.14 & 88.22 & 9.61 & 56.40 & 7.17 & 23.64 & 4.46 & 3.12 & 0.41 \\
\hline 2. & $\begin{array}{l}\text { P. trijenningsi, } \\
\text { KTI }\end{array}$ & 228.15 & 22.78 & 80.66 & 11.32 & 58.46 & 8.76 & 17.40 & 3.85 & 3.01 & 0.53 \\
\hline
\end{tabular}

Table 4

Mean percentage of surviving clones $\left(\mathrm{F}_{1} / \mathrm{F}_{2}\right.$ generations $)$ in strain crosses within the species of the Paramecium jenningsi complex

\begin{tabular}{|l|l|c|c|}
\hline \multicolumn{1}{|c|}{ Species } & \multicolumn{1}{|c|}{ Strain designation } & F1 obtained by crosses & F2 obtained by autogamy \\
\hline P. bijenningsi & MVPI (India) x CS (China) & 91 & 82 \\
\hline P. trijenningsi & KTI (India) x JH (Japan) & 98 & 94 \\
\hline
\end{tabular}

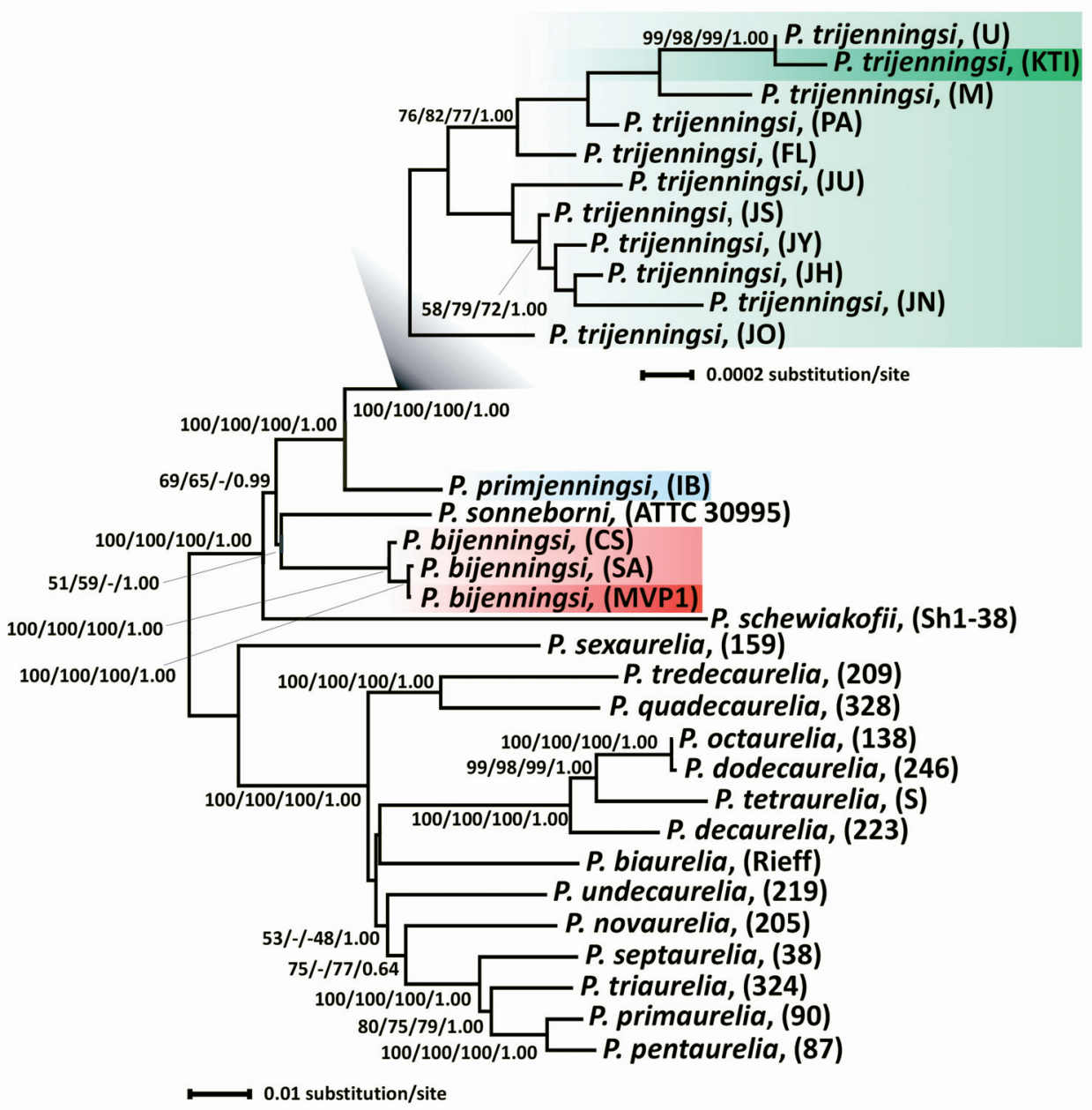

Fig. 2. Unrooted phylogram for 15 P. jenningsi complex strains and 16 other strains of the subgenus Paramecium constructed on the basis of a comparison of eleven concatenated nuclear genome fragments using the neighbor joining method. Bootstrap values for neighbor joining, maximum parsimony, and maximum likelihood analysis, as well as posterior probabilities for Bayesian inference are presented. Bootstrap values of less than $50 \%$ (posterior probabilities of less than 0.50 ) are not shown. All positions containing gaps and missing data were eliminated. There were a total of 3922 positions in the final dataset. Phylogenetic analyses were conducted in MEGA 6.0 (NJ/MP/ML) and MrBayes 3.1.2 (BI). 


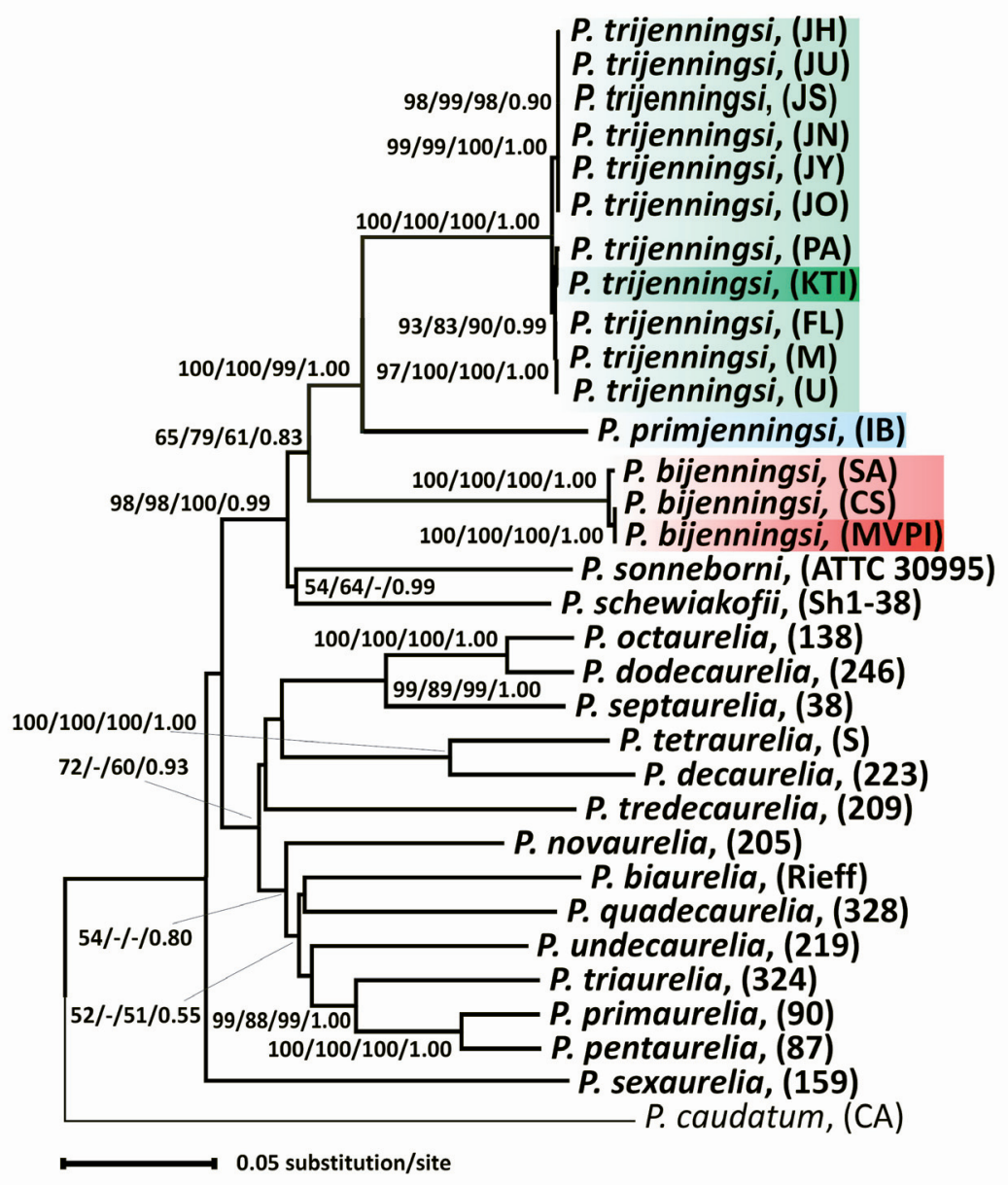

Fig. 3. Phylogram or 15 P. jenningsi complex strains and 17 other strains of the subgenus Paramecium (the CA strain of $P$. caudatum was used as an outgroup) constructed on the basis of a comparison of five concatenated mitochondrial genome fragments using the neighbor joining method. Bootstrap values for neighbor joining, maximum parsimony, and maximum likelihood analysis, as well as posterior probabilities for Bayesian inference are presented. Bootstrap values of less than $50 \%$ (posterior probabilities of less than 0.50 ) are not shown. All positions containing gaps and missing data were eliminated. There were a total of 2553 positions in the final dataset. Phylogenetic analyses were conducted in MEGA 6.0 (NJ/MP/ML) and MrBayes 3.1.2 (BI).

\section{Phylogenetic analysis}

All applied methods (NJ - neighbour-joining, $\mathrm{MP}$ - maximum parsimony, ML - maximum likelihood, BI - Bayesian inference) of tree reconstruction gave an almost identical topology, so in the current study only neighbour-joining phylograms (Figs 2, 3) providing bootstrap/posterior probability values for the other methods are presented. Due to the lack of nuclear sequences for $P$. caudatum (outgroup) it was impossible to obtain a rooted tree for the nucDNA dataset.

Based on the two phylogenetic trees (Figs 2, 3) constructed on the basis of two datasets (nucDNA and $\mathrm{mtDNA}$ ) of 16 sequenced genome fragments, the division of $P$. jenningsi into two clades $(P$. bijenningsi and $P$. trijenningsi $)$ and one branch $(P$. primjenningsi) can be seen. The strains from India identified by cytological characteristics as $P$. jenningsi appear with strong bootstrap support in both trees in two different clades: strain MVPI in the $P$. bijenningsi cluster and strain KTI in the P.trijen- ningsi cluster. The positions of MVPI and KTI strains (Figs 2,3) are in accordance with the results of strain crosses (Table 4). It is worth noting that strain MVPI based on a comparison of the nucDNA dataset (Fig. 2) is most closely related to the $P$. bijenningsi strain from Saudi Arabia (SA) but in the case of the mtDNA dataset (Fig. 3) it appears in one subclade with the $P$. bijenningsi strain from China (CS). A similar situation was observed in the case of the second Indian strain (KTI) which appears in one subclade with the Uganda strain (U) (Fig. 2 -nucDNA tree) and with the Panama strain (PA) (Fig. 3 - mtDNA tree). However, the observed positions did not influence species identification of either of the strains.

\section{Species identification of new Paramecium strains}

Due to the absence of a uniform species definition, the abundance of cryptic diversity, and the occurrence of convergent morphology (BOENIGK 
et al. 2012), different approaches to demarcating boundaries between protist species should be applied (CARON 2013). Likewise in the current survey, except existing cryptic differentiation in $P$. jenningsi morphospecies, the occurrence of paraphyly between $P$. aurelia and $P$. jenningsi complexes (PRZYBOŚ et al. 2015; PRZYBOŚ \& TARCZ 2016; this study Figs 2,3) forced application of morphological studies, strain crosses and multilocus analysis for proper species identification. Based on the obtained results both strains from Andra Pradesh, India are identified as $P$. bijenningsi (strain MVPI) and $P$. trijenningsi (strain $\mathrm{KTI}$ ) - members of the $P$. jenningsi species complex (cf PRZYBOŚ \& TARCZ 2016). What is more, the first description of $P$. jenningsi (DILLER \& EARL 1958) was also based on a strain from Bangalore, India. At present, it is recognized as $P$. primjenningsi (PRZYBOŚ \& TARCZ 2016) of the $P$. jenningsi complex. The studied herein Paramecium species meet the criteria of a species complex (according to BICKFORD et al. 2007) because they can be differentiated based on strain crosses and molecular characteristics but they cannot be differentiated based on morphological features alone. The strains identified in this work as $P$. bijenningsi and $P$. trijennings $i$ were collected and described as $P$. jenningsi (SERRA et al. 2014) but without detailed identification of cryptic species. In 2014 another Indian strain (designated BJ1) was collected in Chilka Lake, Odisha, presenting a macronuclear endosymbiont "Candidatus Gortzia infectiva" (SERRA et al. 2016), a recently described bacterial species originally retrieved in $P$. jenningsi strain TS-j1-8 from Thailand (BOSCARO et al. 2013). Based on the results presented here, the future sampling of tropical regions such as India, which are in general poorly investigated in terms of Paramecium diversity, may reveal new data on biodiversity and biogeography of known or even undiscovered morpho-species.

\section{Acknowledgements}

International mobility of C. KALAVATI, S.I. FOKIN, V. SERRA and C. K. BASURI was supported by the European Commission FP7-PEOPLE-2009-IRSES project CINAR PATHOBACTER (247658), coordinator G. PETRONI. The authors are grateful to the Marine Biology Laboratory, Andhra University, India, for providing the research facilities. In particular, Prof. Raman AKKUR, Prof. Bhagavatula V. SANDEEP and Prof. Prabhakara Rao YALLAPRAGADA are acknowledged for their valuable support. Special acknowledgments to Valentina SERRA and Charan Kumar BASURI who carried out the sampling in India.

\section{References}

BICKFORD D., LOHMAN D.J., SOHDI N.S., NG P.K.L., MEIER R., WINKER K., INGRAM K.K., DAS I. 2007. Cryptic species as a window on diversity and conservation. Trends Ecol. Evol. 22: $148-155$.

BoENigK J., ERESHEFSKY M., HoEF-EMDEN K., MALLET J., BASS D. 2012. Concepts in protistology: species definitions and boundaries. Eur. J. Protistol. 48: 96-102.

Boscaro V., FoKin S.I., Schrallhammer M., SCHWEIKERT M., PETRONI G. 2013. Revised systematics of Holospora-like bacteria and characterization of "Candidatus Gortzia infectiva", a novel macronuclear symbiont of Paramecium jenningsi. Microbiol. Ecol. 65: 255-267.

CARON D.A. 2013. Towards a molecular taxonomy for protists: benefits, risks, and applications in plankton ecology. J. Eukaryot. Microbiol. 60: 407-413.

DILleR W.F., EARL P.R. 1958. Paramecium jenningsi, n. sp. J. Protozool. 5: 155-158.

FOKIN S.I. 1997. Morphological diversity of the micronuclei in Paramecium. Arch. Protistenk. 148: 375-387.

FOKIN S.I. 2010/2011. Paramecium genus: biodiversity, some morphological features and the key to the main morphospecies discrimination. Protistology 6: 227-235.

HALL T.A. 1999. BioEdit: a user-friendly biological sequence alignment editor and analysis program for Windows 95/98/NT. Nucleic Acids Symp. Series 41: 95-98.

MACIEJEWSKA A. 2007. Relationships of new sibling species of Paramecium jenningsi based on sequences of the histone H4 gene fragment. Eur. J. Protistol. 43: 125-130.

Medinger R., Nolte V., PANDEy R.V., Jost S., OTTENWÄLDER B., SCHLÖTTERE C., BOENIGK J. 2010. Diversity in a hidden world: potential and limitation of nextgeneration sequencing for surveys of molecular diversity of eukaryotic microorganisms. Mol. Ecol. 19: 32-40.

MitChell J.B. 1963. Nuclear activity in Paramecium jenningsi with reference to other members of the "aurelia“ group. J. Protozool. 10: 11.

PRZYBOŚ E. 1975. Genetic studies of Paramecium jenningsi strains (Diller and Earl, 1958). Folia Biol. (Kraków) 23: 425-471.

PRZYBOŚ E. 1986. Chromosomes in Paramecium jenningsi (Diller and Earl. 1958): A serial section study. Folia Biol. (Kraków) 34: 133-160.

PrZyboś E., Fokin S., Stoeck T., SchmidT H.J. 1999. Occurrence and ecology of Paramecium jenningsi. Folia Biol. (Kraków) 47: 53-59.

Przyboś E., SkotarczaK B., Wodecka B. 2003. Phylogenetic ralationships of Paramecium jenningsi strains (classical analysis and RAPD studies). Folia Biol. (Kraków) 51: 85-95.

PRZYBOŚ E., TARCZ S. 2013. Three-locus analysis in conjunction with strain crosses confirms the existence of reproductively isolated populations in Paramecium jenningsi (Diller and Earl 1958). Syst. Biodiver. 11: 507-523.

PrZyboŚ E., TARCZ S., RAUTIAN M., SAWKa N. 2015. Delimiting species boundaries within a parapyletic species complex: Insights from morphological, genetic, and molecular data on Paramecium sonneborni (Paramecium aurelia species complex, Ciliophora, Protozoa). Protist 166: 438-456.

PRZYBOŚ E., TARCZ S. 2016. Paramecium jenningsi complex - existence of three cryptic species confirmed by multi-locus analysis and strain crosses. Syst. Biodivers. 14: 140-154.

SERRA V., CASTElli M., BASURI C.K., Illa K.V., SABANEYEVA E., SANDEEP B.V., PETRONI G. 2014. Survey of endosymbiotic bacteria in ciliates from India. Frontiers in 
ciliate genome evolution, adaptation, and symbiosis. GDRE, BMBS COST Action BM1102 and IRSES CINAR PATHOBACTER joint meeting. 5-9 October 2014, Pisa. Abstracts: 35.

SERRA V., FoKIN S.I., CASTELli M., BASURI C.K., NITIA V., VERni F., SANDEEP B.V., KalaVATI C., PETRONI G. 2016.

"Candidatus Gortzia Shahrazadis", a novel endosymbiont of Paramecium multimicronucleatum and a revision of the biogeographical distribution of Holospora-like bacteria. Front. Microbiol. 7: 1704.
SONNEBORN T. M. 1950. Methods In the general biology and genetics of Paramecium. J. Exp. Zool. 113: 87-148.

SONNEBORN T. M. 1970. Methods in Paramecium research. In: Prescott D.M. ed. Methods in Cell Physiology, vol.4. Academic Press, New York, London, : 241-339

ThOMPSON J.D., HIGGINS D.G., GIBSON T.J. 1994. Clustal W: improving the sensitivity of progressive multiple sequence alignment through sequence weighting, positionspecific penalties and weight matrix choice. Nuc. Acids Res. 22: $4673-80$ 